HAMLET AND THE VISION OF DARKNESS 



\section{Hamlet and the Vision of Darkness}

pannesers

Rhodri Lewis 
Copyright (C) 2017 by Princeton University Press

Published by Princeton University Press,

41 William Street, Princeton, New Jersey 08540

In the United Kingdom: Princeton University Press,

6 Oxford Street, Woodstock, Oxfordshire OX20 1TR

press.princeton.edu

Cover art: Piero di Cosimo (Piero di Lorenzo di Piero d'Antonio), A Hunting Scene, c. 1494150o. Gift of Robert Gordon, 1875 / The Metropolitan Museum of Art, New York

Cover design by Leslie Flis

Excerpt from "Sprich auch du," Paul Celan, Von Schwelle zu Schwelle (c) 1955, Deutsche Verlags-Anstalt, Munchen, in der Verlagsgruppe Random House GmbH.

Excerpt from Seven Types of Ambiguity copyright William Empson, 1930.

Excerpt from How It Is by Samuel Beckett, English translation copyright (C) 1964 by Grove Press, Inc. Used by permission of Grove/Atlantic, Inc. and Faber \& Faber Ltd. Any third party use of this material, outside of this publication, is prohibited.

Excerpt from "Good Writers and Good Readers" from Lectures on Literature by Vladimir Nabokov. Copyright (C) 1980 by the Estate of Vladimir Nabokov. Reprinted by permission of Houghton Mifflin Harcourt Publishing Company. All rights reserved.

All Rights Reserved

First paperback printing, 2020

Paperback ISBN 978-0-691-20451-2

The Library of Congress has cataloged the cloth edition as follows:

Names: Lewis, Rhodri, 1976- author.

Title: Hamlet and the vision of darkness / Rhodri Lewis.

Description: Princeton : Princeton University Press, 2017. | Includes bibliographical references and index.

Identifiers: LCCN 2017003227 | ISBN 9780691166841 (hardback : acid-free paper)

Subjects: LCSH: Shakespeare, William, 1564-1616. Hamlet.

Classification: LCC PR2807 .L47 2017 | DDC 822.3/3-dc23 LC record available at https://lccn .loc.gov/2017003227

British Library Cataloging-in-Publication Data is available

This book has been composed in Miller

Printed on acid-free paper. $\infty$

Printed in the United States of America 
For Sarah, and for Max 

quid dubitas quin omnis sit haec rationis potestas, omnis cum in tenebris praesertim vita laboret? nam vel uti pueri trepidant atque omnia caecis in tenebris metuunt, sic nos in luce timemus interdum nihilo quae sunt metuenda magis quam quae pueri in tenebris pavitant finguntque futura. hunc igitur terrorem animi tenebrasque necessest non radii solis neque lucida tela diei discutiant, sed naturae species ratioque.

LUCRETIUS, DE RERUM NATURA

Falsehood is so easy, truth so difficult. The pencil is conscious of a delightful facility in drawing a griffin-the longer the claws, and the larger the wings, the better; but that marvellous facility which we mistook for genius is apt to forsake us when we want to draw a real unexaggerated lion. Examine your words well, and you will find that even when you have no motive to be false, it is a very hard thing to say the exact truth, even about your own immediate feelings-much harder than to say something fine about them which is not the exact truth.

GEORGE ELIOT, $A D A M B E D E$

Wahr spricht, wer Schatten spricht.

PAUL CELAN, "SPRICH AUCH DU" 
